\title{
Spatial variation in density, mean size and physiological condition of the holarctic amphipod Diporeia spp. in Lake Michigan
}

\author{
THOMAS F. NALEPA,* DAVID J. HARTSON,† JENNIFER BUCHANAN,† JOANN F. CAVALETTO,* \\ GREGORY A. LANG* AND STEPHEN J. LOZANO \\ ${ }^{*}$ Great Lakes Environmental Research Laboratory, National Oceanic and Atmospheric Administration, 2205 Commonwealth \\ Blvd., Ann Arbor, MI 48105, U.S.A. \\ †Cooperative Institute for Limnology and Ecosystems Research, University of Michigan, 2200 Bonisteel Blvd., Ann Arbor, MI \\ 48109, U.S.A. \\ ‡U.S. Environmental Protection Agency, Mid-Continent Ecology Division, 6201 Congdon Blvd. Duluth, MN 55804, U.S.A.
}

\section{SUMMARY}

1. We examined spatial patterns in population characteristics (density, biomass, mean body length) and physiological condition (lipid content, length-weight) of the amphipod Diporeia spp. in Lake Michigan by collecting samples at up to 85 sites in late summer 1994 and 1995. Variables were examined relative to water depth and three lake regions: south, central and north. Most major river systems are found in the south, and this region is more nutrient-enriched compared to the north.

2. Over all sites, mean density was $5240 \mathrm{~m}^{-2}$, biomass was $4.1 \mathrm{~g}$ dry $\mathrm{wt} \mathrm{m}^{-2}$, and mean body length was $5 \mathrm{~mm}$. While maximum densities were related to depth, with a peak at 30-70 m, greatest densities occurred on the west side of the lake, and low densities were found in the south-east, north-east and lower Green Bay. High densities in the west probably resulted from upwelling, and reduced densities in the south-east may reflect food competition with Dreissena polymorpha (zebra mussel).

3. Lipid content, weight per unit length, and mean length declined with increased water depth, but depth-related trends were most evident in the south. Overall, mean lipid content and weight per unit length were significantly lower in the south $(16.6 \% \mathrm{dry} \mathrm{wt}$, $0.59 \mathrm{mg}$ at $5 \mathrm{~mm}$ body length) compared to the north (23.7\% dry wt, $0.78 \mathrm{mg}$ at $5 \mathrm{~mm}$ body length). These regional differences may have resulted from greater diatom availability in the north and competition from D. polymorpha in the south. Triacylglycerols and phospholipids were the dominant lipid classes in all three regions. Although the mean proportion of triacylglycerols, the energy-storage lipid, was lower in the south than in the north, regional differences in proportions of lipid classes were not significant.

4. Mean lipid content and weight per unit length of Diporeia in the south were lower than values found in the late 1980s prior to the establishment of Dreissena. Mean lipid content of mature individuals is now at levels considered a minimum for successful reproduction.

Keywords: lipid content, lipid classes, length-weight, Dreissena, Great Lakes

Correspondence: Thomas F. Nalepa, Great Lakes Environmental Research Laboratory, National Oceanic and Atmospheric Administration, 2205 Commonwealth Blvd., Ann Arbor, MI 48105, U.S.A. E-mail: nalepa@glerl.noaa.gov 


\section{Introduction}

The benthic amphipod Diporeia spp. is a member of a holarctic group of related amphipod genera that occupy northern proglacial lakes, brackish seas and arctic estuaries (Bousfield, 1989). Within their geographical range, these amphipods generally dominate the benthic fauna of offshore communities, and provide a major food-web link between pelagic production and upper trophic levels (Cederwall, 1977; Gardner et al., 1990; Johnson \& Wiederholm, 1992). As detritivores, they ingest organic material freshly settled from the pelagic region and, in turn, are fed upon by many species of fish. Because of this ecosystem role, relationships between environmental conditions and amphipod physiological state have been the subject of a number of investigations, particularly for Diporeia in the North American Great Lakes (Gardner et al., 1985a; Gauvin, Gardner \& Quigley, 1989; Quigley, Chandler \& Gardner, 1989; Cavaletto et al., 1996), and for Monoporeia affinis and Pontoporeia femorata in the Baltic Sea (Hill et al., 1992; Lehtonen, 1995, 1996).

In this paper, we document population parameters and physiological condition of Diporeia over a broad area in Lake Michigan. As an important indicator of physiological condition, we place particular emphasis on spatial patterns in lipid content. Lipids have twice the energy content of proteins or carbohydrates (Hadley, 1985), and are an integral component in the feeding strategy of this organism. As a glacial marine relict, Diporeia prefers the constantly cold temperatures of environments below the thermocline in temperate regions (Dadswell, 1974). At these depths, benthic food inputs can vary seasonally. In Lake Michigan, most input of food to the benthic region occurs during the spring diatom bloom (Scavia et al., 1986; Gardner et al., 1989). Diatoms are a high-quality food source and the preferred food of Diporeia and related species (Quigley \& Vanderploeg, 1991; Johnson \& Wiederholm, 1992). Diporeia responds to seasonal variation in food by accumulating lipids during periods of greatest food inputs, and then utilizing them as an energy source when food is scarce (Gardner et al., 1990). This life habit of lipid accumulation and utilization is similar to amphipod species found in the Baltic Sea where food inputs also vary seasonally (Hill et al., 1992; Lehtonen, 1996), but contrasts with stable lipid levels of amphipods inhabiting lakes with a more constant food supply (Moore, 1976; Napolitano \& Ackman, 1989). Besides providing a source of energy, lipid stores are also used in the development of reproductive tissue and embryos, and threshold levels are generally necessary for reproduction to be successful (Clarke, Skadsheim \& Holmes, 1985; Hill et al., 1992).

While previous studies have characterized various aspects of the Diporeia population in Lake Michigan, including lipid content, these studies have been conducted solely in the southern basin of the lake (Winnell \& White, 1984; Gardner et al., 1985a, 1989; Nalepa, 1987, 1989; Quigley, Chandler \& Gardner, 1989; Cavaletto et al., 1996). The southern basin is the most enriched of Lake Michigan's open-lake basins (Schelske, 1977) and thus population characteristics and physiological condition of Diporeia may be different from other lake basins. Our results may also help explain the recent decline of Diporeia in the south/south-eastern portion of the lake (Nalepa et al., 1998) by providing a lakewide perspective to the population's physiological condition.

\section{Methods}

\section{Sampling and analysis}

Diporeia was collected at eighty-five sites during two sampling cruises in late summer 1994 (late July and early September), and one cruise in late summer 1995 (late August/early September) (Fig. 1). The sites were part of three separate sampling programs in Lake Michigan: Environmental Monitoring and Assessment (EMAP), Lake Michigan Mass Balance (LMMB), and Long-Term Macroinvertebrate Monitoring (LTMM). Site locations in EMAP were based on a random, probabilistic design (Stevens, 1997) within the $85 \mathrm{~m}$ depth contour, site locations in LMMB were focused in offshore, depositional areas, and site locations in the LTMM program were located at various depths in the southern portion of the lake. Samples for density estimates were taken in triplicate at each of the sites with a Ponar grab (sampling area $=0.046 \mathrm{~m}^{2}$ ). Sediments were washed through an elutriation device fitted with a $0.5-\mathrm{mm}$ mesh net, and retained residue was preserved in 5\% formalin containing rose bengal stain (Nalepa et al., 1985).

In the laboratory, animals were picked and counted under a low-power magnifier lamp (1.5x). Body 


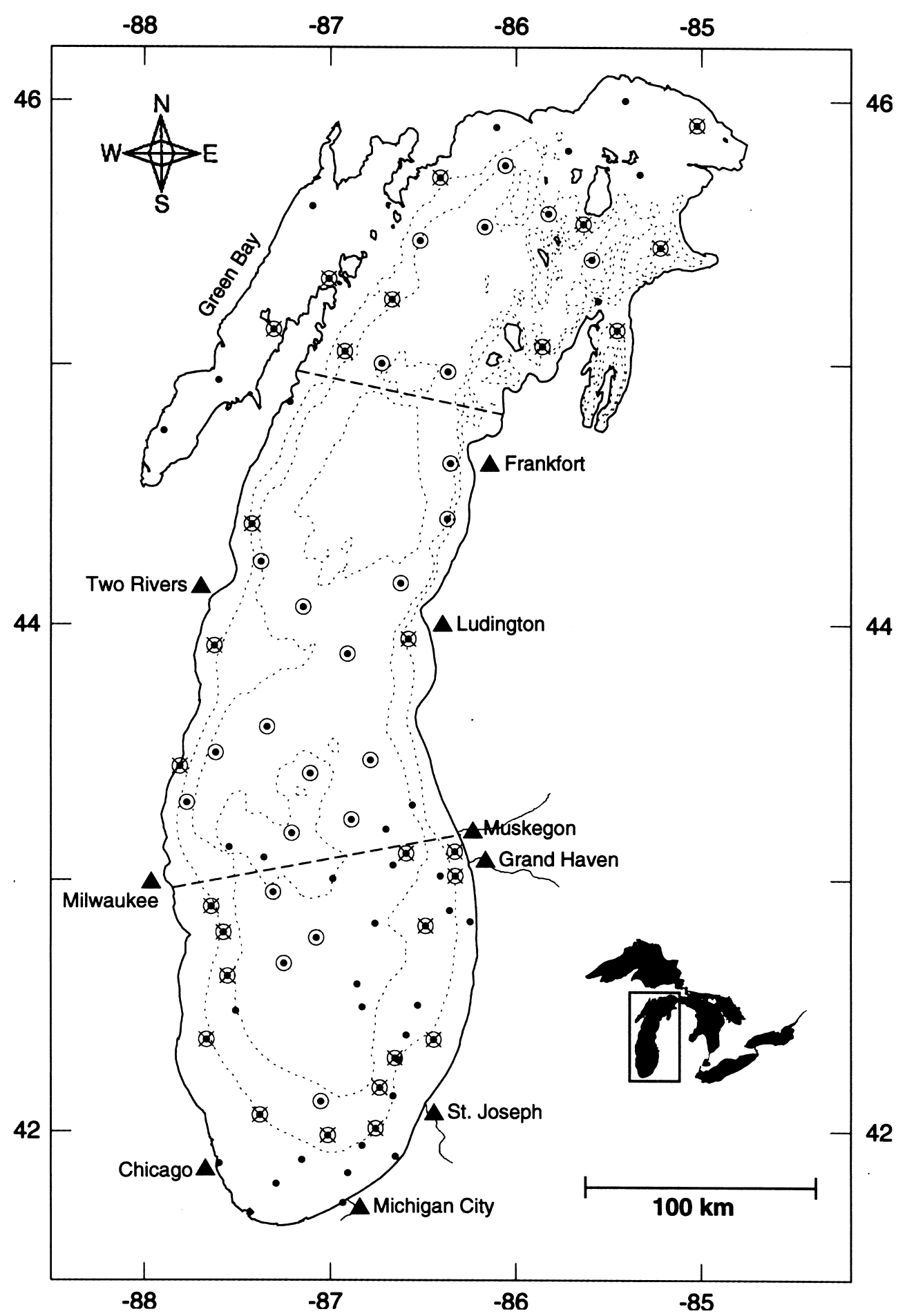

Fig. 1 Location of sampling sites in Lake Michigan in 1994 and 1995. Density and mean size of Diporeia were obtained at each of the sites. Lipid content was measured at each of the circled sites, and length-weight was measured at each of the sites with an X. Depth contours are 50, 90, $150 \mathrm{~m}$. Dashed lines separate the south, central, and north regions.

lengths were determined by first tracing individuals under $12 \times$ magnification using a camera lucida, and then measuring the tracings with a digitizer (Quigley
\& Lang, 1989). In replicates with high numbers of individuals, animals were subsampled using a Folsom plankton splitter, and lengths determined on at least 
110 T. F. Nalepa et al.

75-100 individuals. Animals were placed into 1-mm size categories for calculation of size-frequency distributions and mean length at a given site.

During the first sampling cruise in 1994, in which samples were collected at the EMAP and LTMM sites, extra grabs were taken at sites with abundant Diporeia for determination of lipid content and length-weight. Individuals in extra samples from these sites (28 total) were separated into four size classes based on approximate body length $(<3 \mathrm{~mm}, 3-5 \mathrm{~mm}, 5-$ $7 \mathrm{~mm}$, and $>7 \mathrm{~mm}$ ). The animals were separated within $4 \mathrm{~h}$ of collection using a low-power binocular microscope. Except for animals in the $<3 \mathrm{~mm}$ size class, about 5-7 animals in each size category were placed individually into preweighed mini-test tubes $(6 \times 50 \mathrm{~mm})$. For the smallest size class, 3-5 animals were placed into of at least three replicate tubes. Before the animals were placed into the tubes, individual lengths were traced and later measured as stated above. These samples were weighed (after drying and just prior to lipid analysis) and were used for determination of length-weight relationships. Animals for lipid analysis were not collected during the second cruise in 1994. On the 1995 cruise, animals were collected from twenty four sites for determination of lipid content, but exact lengths were not measured; instead, animals were placed into three relative size categories (small, medium, and large) before being put individually into the tubes.

Animals for lipid content analysis were dried (under $\mathrm{N}_{2}$, at $50-60{ }^{\circ} \mathrm{C}$ ) for $48 \mathrm{~h}$, and stored frozen under vacuum until lipid extraction. Total lipids were extracted using chloroform:methanol (2:1), quantified gravimetrically, and reported as percentage of dry weight (Gardner et al., 1985b). Lipid classes were determined on a portion of the final lipid extract using thin layer chromatography with flame ionization detection (Parrish, 1987).

Since length-weight was obtained from only those sites with abundant Diporeia on the first cruise in 1994 (sites = 28; Fig. 1), while density and size-frequency were obtained from all sites $(n=85)$, we grouped sites into four depth intervals $(<30,30-50,51-90$, and $>90 \mathrm{~m}$ ) and calculated a length-weight relationship for each interval using individuals from sites within the interval. This length-weight relationship was then used to calculate dry-weight biomass at all sites in that depth interval. The depth intervals are consistent with prior characterization of associations between water depth and macroinvertebrates in Lake Michigan (Alley \& Mozley, 1975; Nalepa, 1987).

\section{Regions in Lake Michigan}

We examined population parameters (density, biomass, mean size) and physiological condition (lipid content, length-weight) in relation to water depth and to three regions of the lake: south, central and north. Lake Michigan extends about $500 \mathrm{~km}$ along a northsouth axis, and the south and north portions of the lake have different catchments, nutrient loads, and trophic conditions (Bartone \& Schelske, 1982; Meyers $\&$ Eadie, 1993). Catchments in the south contain large population centres, industrial complexes, and drain mostly farmlands, while catchments in the north are generally rural and forested. Most major tributaries are found in the south, and $40 \%$ of all nutrient loads enter the lake in this region (Robertson, 1997). Tributaries entering Green Bay contribute another $35 \%$ of total nutrient loads; however, the enriching effects of these nutrients are mostly manifested in the bay itself and not in the open waters of the northern region (Schelske, 1977). Because of higher tributary inputs, total deposition of particulate mass and organic carbon is higher in the south (Meyers \& Eadie, 1993). In the 1970s, water temperatures and total phosphorus concentrations were significantly higher in the south than in the north, while water transparency was significantly lower (Bartone \& Schelske, 1982).

We defined the southern region as the area south of a midlake, bedrock plateau extending approximately between Milwaukee and Muskegon (Fig. 1). This region, known as the southern depositional basin, has a gentle slope and a maximum depth of $163 \mathrm{~m}$. The central region extends from the mid-lake plateau north to the Door-Leelanau Ridge (just north of Frankfort) (Fig. 1). This region includes a mid-lake ridge (Two Rivers Ridge) which extends from Ludington to Two Rivers, and several depositional basins, including the deepest basin in the lake $(240 \mathrm{~m})$. The north region is the area north of the Door-Leelanau Ridge; bottom topography in this region is complex, consisting of many ridges and valleys.

In defining our regions, we sought to keep mean sampling depths in the south and north as similar as possible for sites greater than $30 \mathrm{~m}$ where physiolo- 
gical condition was measured; mean depth at sites where lipid content was measured was $76 \mathrm{~m}$ in the south and $83 \mathrm{~m}$ in the north, while the mean depth for sites where length-weight was measured was $58 \mathrm{~m}$ in the south and $51 \mathrm{~m}$ in the north. The central region was considered a transitional area between the more clearly defined and contrasting environmental conditions found in the south and north.

\section{Data Analysis}

Unless otherwise noted, regional and depth-related trends in Diporeia physiological condition were examined only for sites deeper than $30 \mathrm{~m}(n=67)$. These sites are located below the thermocline where near-bottom water temperatures are generally uniform, and oxygen concentrations are at or near saturation. Thus, spatial differences in these variables would have little impact on regional comparisons. Although we only sampled in late summer, growth patterns and size frequencies of Diporeia populations do not vary over a seasonal period at these deeper depths because of overlapping cohorts (Winnell \& White, 1984; Evans, Quigley \& Wojcik, 1990). Regiondepth comparisons were facilitated by dividing the sites into three depth intervals, 30-50 m, 51-90 m, and greater than $90 \mathrm{~m}$.

\section{Results}

Population variables

Mean density at all sites was $5243 \mathrm{~m}^{-2}$ (range 0$\left.14566 \mathrm{~m}^{-2}\right)$, and mean dry-wt biomass was $4.1 \mathrm{~g} \mathrm{~m}^{-2}$ (range 0-15.8 $\mathrm{g} \mathrm{m}^{-2}$ ). In general, maximum densities increased with water depth to reach a peak at depths between 30 and $70 \mathrm{~m}$ and then declined (Fig. 2). On a regional basis, mean densities were greatest at the 30$50 \mathrm{~m}$ interval in the southern region, but greatest at the 51-90 m interval in the central and northern regions (Table 1). However, maximum site-specific densities occurred in the 30-50 m interval in all three regions.

Greatest densities occurred along the west side of the lake (Fig. 3a). Of the seven sites having a density greater than $10000 \mathrm{~m}^{-2}$, six occurred on this side. In contrast, densities were lowest in the far south/southeastern and north-eastern portions of the lake, and in lower Green Bay. Spatial patterns in biomass were similar to those for density (Fig. 3b).

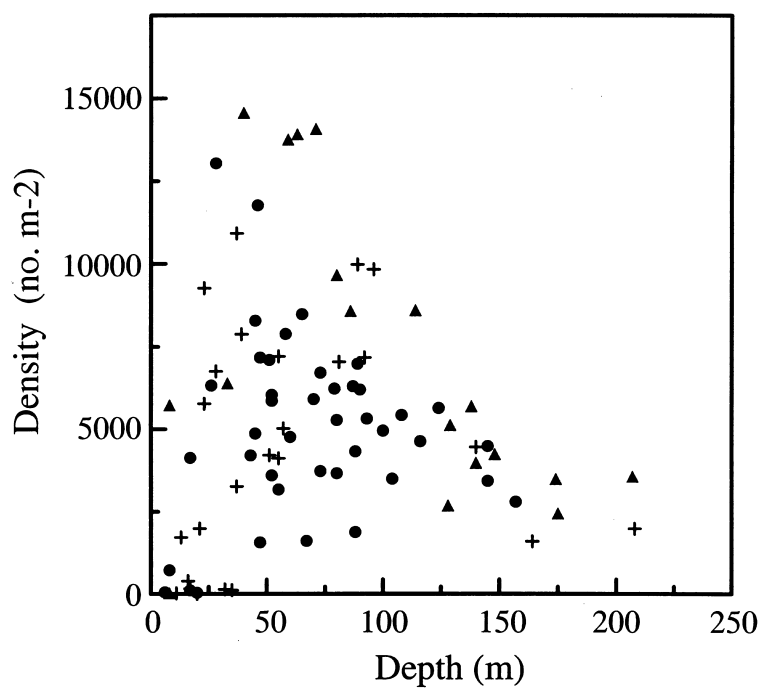

Fig. 2 Relationship between sampling depth (meters) and density (no. $\mathrm{m}^{-2}$ ) of Diporeia at eighty-five sites sampled in Lake Michigan in late summer 1994 and 1995. Each point represents a mean of three replicates; South Region $(\bullet)$, Central Region $(\boldsymbol{\Lambda})$, North Region (+).

Mean body length was $5 \mathrm{~mm}$ and ranged from 3.6 to $6.7 \mathrm{~mm}$ at individual sites. Although there was a significant negative relationship between mean length and water depth overall (linear regression, $P<0.001$, Fig. 4a), regional regressions indicated the relationship was only significant in the south $(P<0.001)$. For the north, mean body length was highly variable, particularly for sites in the 30-50 m interval (Fig. 4a). Despite high variation, mean length was significantly higher in the south than in the north at this interval (Table 1).

\section{Physiological condition}

In Diporeia and related amphipod species such as M. affinis and P. femorata from the Baltic Sea, lipids are accumulated as the organisms grow, and a simple linear model has been used to describe the relationship between lipid content (mg lipid dry weight) and dry mass (mg lipid-free dry weight) (Quigley, Chandler \& Gardner, 1989; Hill et al., 1992; Lehtonen, 1996). Although the linear model was significant for our lakewide data, the power model $\left(\mathrm{LDW}=\mathrm{aLFDW}^{\mathrm{b}}\right.$ where $\mathrm{LDW}=$ lipid dry weight and LFDW = lipid free dry weight) provided the better fit (power model: $R^{2}=0.770, P<0.001$; linear model: $R^{2}=0.653, P<0.001$ ). The power model was significant for individuals in each of the three 
Table 1 Mean density (no. $\mathrm{m}^{-2}$ ), body length ( $\mathrm{mm}$ ), lipid content (\% of dry weight), and weight (mg of a standard 5-mm animal) of Diporeia at each of three depth intervals in the south, central, and north regions of the lake. The number in parentheses is the number of sites in each category. $P$-values are from an ANOVA testing regional differences for each depth interval (ns $=$ not significant). Values followed by different letters are significantly different from each other (Tukey HSD, $P<0.05$ )

\begin{tabular}{|c|c|c|c|c|c|}
\hline Depth interval & & Density & Mean length & Lipid & Weight \\
\hline \multicolumn{6}{|l|}{$30-50 \mathrm{~m}$} \\
\hline & South & $6309(6)$ & $6.1(6)^{\mathrm{a}}$ & $17.4(4)^{\mathrm{a}}$ & $0.68(4)$ \\
\hline & Central & 10477 (2) & $5.0(2)^{\mathrm{ab}}$ & $22.3(2)^{\mathrm{ab}}$ & $0.85(2)$ \\
\hline & North & $4462(5)$ & $4.4(5)^{\mathrm{b}}$ & $27.5(3)^{\mathrm{b}}$ & $0.70(2)$ \\
\hline & & ns & $P<0.05$ & $P<0.05$ & ns \\
\hline \multicolumn{6}{|l|}{$51-90 \mathrm{~m}$} \\
\hline & South & $5285(20)^{\mathrm{a}}$ & $5.2(20)^{\mathrm{ab}}$ & $17.6(9)^{\mathrm{a}}$ & $0.54(8)^{\mathrm{a}}$ \\
\hline & Central & $11997(5)^{\mathrm{b}}$ & $4.6(5)^{\mathrm{b}}$ & $19.7(5)^{\mathrm{a}}$ & $0.67(1)^{\mathrm{a}}$ \\
\hline & North & $6262(6)^{a}$ & $5.5(6)^{\mathrm{a}}$ & $27.5(6)^{\mathrm{b}}$ & $0.78(5)^{\mathrm{b}}$ \\
\hline & & $P<0.05$ & $P<0.01$ & $P<0.01$ & $P<0.05$ \\
\hline \multicolumn{6}{|l|}{$>90 \mathrm{~m}$} \\
\hline & South & $4466(9)$ & $4.8(9)$ & $13.8(4)$ & $0.52(1)$ \\
\hline & Central & 4443 (9) & $4.5(9)$ & $13.6(9)$ & - \\
\hline & North & $5007(5)$ & $4.6(5)$ & $16.8(5)$ & - \\
\hline & & $\mathrm{ns}$ & ns & ns & - \\
\hline
\end{tabular}

regions (Table 2), and a subsequent comparison of the regional models indicated that they were significantly different from each other (ANCOVA; $P<0.001, \log$ transformed). Lipid content increased from south to north; a standard individual of $1.5 \mathrm{mg}$ dry weight had a lipid weight of $0.34,0.37$, and $0.57 \mathrm{mg}$ in the south, central, and north regions, respectively. As a percentage of dry mass, mean ( \pm SD) lipid content of Diporeia in the three regions was $16.6 \pm 4.1 \quad(n=17), \quad 16.6 \pm 5.8 \quad(n=16)$, and $23.7 \% \pm 7.3 \quad(n=14)$, respectively. Lipid content decreased with increased water depth over all sites and for each region (Fig. $4 \mathrm{~b}$, linear regression, $P<0.05)$. When lipid content in each of three regions were compared within a depth interval, lipid content was significantly $(P<0.05)$ greater in the north than in the south in the $30-50 \mathrm{~m}$ and 51$90 \mathrm{~m}$ intervals, but not in the $>90 \mathrm{~m}$ interval (Table 1).

Since mean lipid content at maturity plays an important role in the reproductive success of amphipods (Clarke et al., 1985; Hill et al., 1992), we also examined the mean lipid content of only large, mature individuals. In Lake Michigan, Diporeia becomes mature at a size of about $6 \mathrm{~mm}$ (Winnell \& White, 1984). When only individuals of this body length or greater were considered, regional differences were even more pronounced; mean lipid content of these mature indivi- duals was $20.3(n=120), 27.5(n=38)$, and $33.5 \%$ dry mass $(n=108)$ in the south, central and north regions, respectively.

Triacylglycerols (TAG) and phospholipids (PHL) were the dominant lipid classes, accounting for a mean of $81 \%$ of total lipid content at all sites (Table 3). TAG is the main energy storage lipid, while phospholipids are structural lipids present in cell membranes. Although the percentage of TAG tended to increase from south to north, regional differences in the proportion of lipid classes were not significant (Gtest; $P>0.05)$. The mean proportion of TAG was higher for mature individuals $(6 \mathrm{~mm})$, but regional patterns were also not apparent; mean TAG content of mature individuals was 51,59, and 55\% total lipid in the three regions, respectively. Trends relative to water depth in TAG and PHL varied. The percentage of PHL declined with depth (linear regression; $P<0.001$ ), but the percentage of TAG did not (linear regression; $P=0.41$ ). The percentage of TAG was highly variable for a given depth, and maximum percentages tended to increase to a peak around $100 \mathrm{~m}$ and then decline.

The length-weight relationship derived from individuals over the whole lake, as well as length-weight relationships derived separately from individuals in each of the three regions, was described by $D W=a L^{b}$, where $D W=$ dry weight $(\mathrm{mg})$ and $L=$ length $(\mathrm{mm})$ 

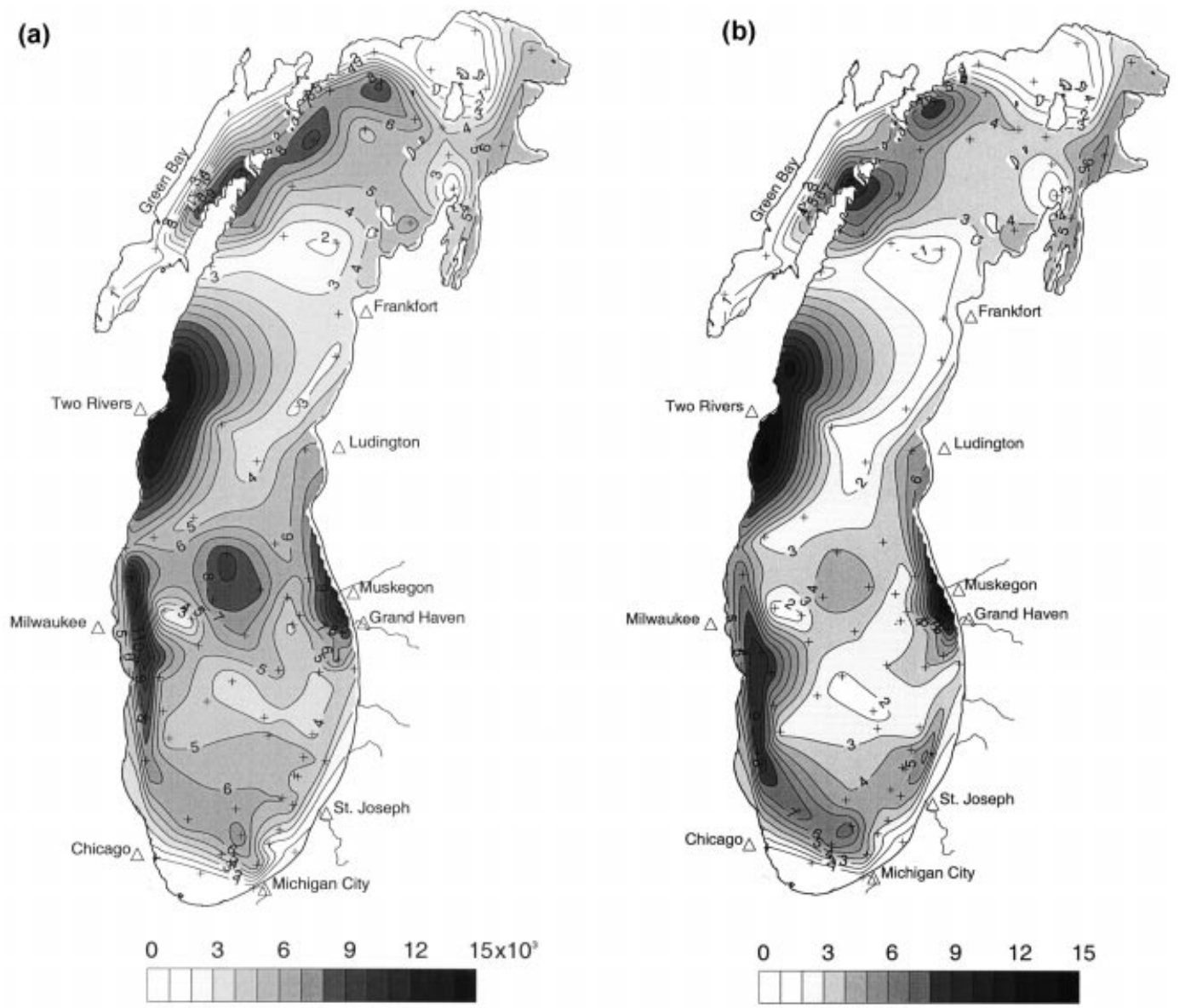

Fig. 3 Spatial patterns in density (a) (no. $\left.\mathrm{m}^{-2} \times 10^{-3}\right)$, and biomass (b) (g dry wt $\mathrm{m}^{-2}$ ) of Diporeia in Lake Michigan in late summer 1994 and 1995.

(Table 4). As found for lipid content, there was a significant difference among the three regions (ANCOVA; $P<0.001, \log$ transformed), with weight per unit length increasing from south to north. From each of the regional models, the dry weight of a standard 5-mm individual was $0.59,0.63$, and $0.78 \mathrm{mg}$ in the south, central and north regions.

Even though the number of sites for which lengthweight relationships were obtained was limited $(n=28)$, there was a significant inverse relationship between the weight of a standard 5-mm animal and water depth (Fig. 4c; linear regression; $P<0.01$ ). When standard weight vs. depth was examined separately for sites in the south and north regions (central region excluded because of only three sites), the relationship was highly significant in the south ( $\left.n=13, R^{2}=0.5513, P<0.01\right)$, but not significant in the north $\left(n=7, R^{2}=0.002, P=0.925\right)$. However, given the low number of sampling sites and limited range of sampling depths in the north, the probability of detecting a relationship was very low.

Pearson correlation analysis between population variables (mean density, mean size) and physiological condition (mean lipid content, length-weight) over all sites indicated that the only significant relationship was between mean lipid content and length-weight $(P<0.05)$. Multiple correlation analysis with Bonferroni-adjusted probabilities indicated all correlations were non-significant.

\section{Discussion}

The observed relationship between Diporeia density and water depth is similar to that described previously in Lake Michigan (Alley \& Mozley, 1975; Mozley \& Howmiller, 1977; Nalepa, 1989), and is 

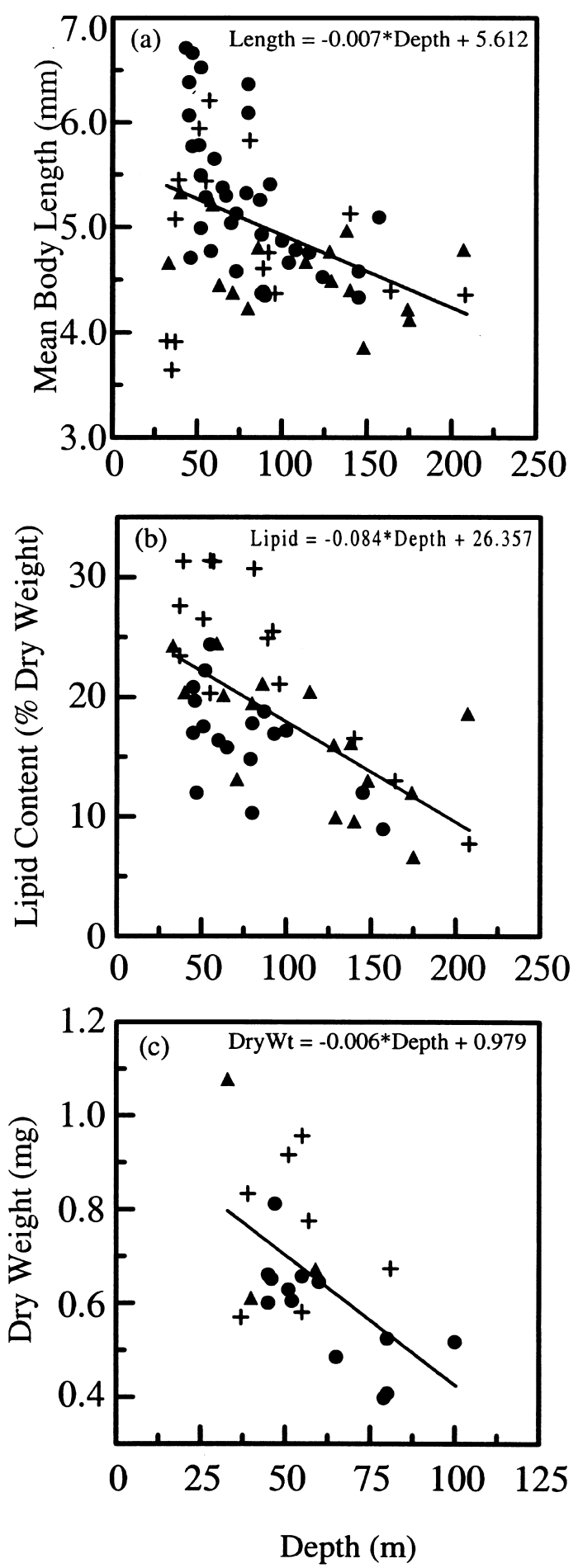

Fig. 4 Relationships between water depth and mean body length (a), mean lipid content (b) and dry weight of a standard 5-mm individual (c) at the sampling sites in Lake Michigan. $R^{2}$ values for the linear regressions were $0.18,0.39$ and 0.31 , respectively. Log transformation of the dependent variable gave values of $0.17,0.44$ and 0.35 . Each point represents a site mean; South Region $(\bullet)$, Central Region (₫), North Region (+). typical for Diporeia in the Great Lakes (Cook \& Johnson, 1974; Sly \& Christie, 1992). Generally, densities increase to a peak at depths just below the thermocline and then decline. At these depths, bottom temperatures are more stable and consistently cold compared to shallower depths, and organic matter settled from the pelagic region is less subject to waveinduced resuspension. As depth increases, the quantity and quality of food that reaches the benthic region is diminished because of lower pelagic productivity in offshore waters, and increased decomposition in the water column during settlement.

As evidenced by the wide variation between density and depth at individual sites (Fig. 2), it is obvious that other factors besides depth-influenced food inputs contributed to spatial distribution patterns. For instance, densities were consistently higher along the west side of the lake than along the east side. Given the predominant south-westerly winds during the period of stratification (June to October), the west side is more prone to upwelling events (Mortimer, 1975). Subsequently, this area is characterized by cooler water temperatures and greater productivity, conditions that tend to favour higher Diporeia abundances (Alley \& Mozley, 1975; Lubner, 1979). Densities were particularly high on the west side of Two Rivers Ridge, and on both the east and west side of the mid-lake plateau. Both these areas are located near major depth changes and intersecting basin gyres, further contributing to the occurrence of upwellings (Mortimer, 1975).

In contrast, relatively low densities were evident in the south/south-eastern and north-eastern portions of the lake, and in lower Green Bay. Low densities in the south/south-eastern portion are likely due to reduced food availability caused by the filtering activities of the zebra mussel, Dreissena polymorpha (Nalepa et al., 1998). D. polymorpha became established in southern Lake Michigan in 1989 and attained high densities by 1993 (Marsden, Trudeau \& Keniry, 1993). Diporeia utilizes freshly settled organic matter as a food source which may be intercepted by $D$. polymorpha before it settles to the bottom. In the profundal region of eastern Lake Erie, Diporeia declined by $88 \%$ after Dreissena became established; also, there was a direct inverse relationship between numbers of Diporeia and Dreissena in individual samples (Dermott \& Kerec, 1997). Reasons for low densities in the far northeastern region of the lake are not entirely clear. A lake- 
Table 2 Relationship between lipid-free dry weight and lipid dry weight for Diporeia in the south, central and north regions of Lake Michigan The relationship is defined by: $\ln L D W=a+b^{*} \ln L F D W$, where $L D W=$ lipid dry weight $(\mathrm{mg})$ and $L F D W=$ lipid-free dry weight $(\mathrm{mg})$. Standard error given in parentheses, $n=$ total number of animals

\begin{tabular}{lllll}
\hline Region & $a$ & $b$ & $n$ & $r^{2}$ \\
\hline South & $-1.614(0.041)$ & $1.308(0.049)$ & 291 & 0.711 \\
Central & $-1.566(0.039)$ & $1.410(0.043)$ & 277 & 0.796 \\
North & $-1.148(0.038)$ & $1.438(0.038)$ & 309 & 0.820 \\
Lake-Wide & $-1.425(0.023)$ & $1.407(0.026)$ & 877 & 0.770 \\
\hline
\end{tabular}

wide study of oligochaete distributions found an unusually high percentage of eutrophic-indicator species in the north-eastern region that similarly could not be explained (Lauritsen, Mozley \& White, 1985). Although Dreissena is present in lower Green Bay, densities of Diporeia in this area have been historically low as a result of shallow depths and warm water temperatures (Mozley \& Howmiller, 1977).

As noted, a linear relationship between lipid content and dry mass has been documented for Diporeia in Lake Michigan, and for M. affinis and P. femorata in the Baltic Sea (Quigley, Chandler \& Gardner, 1989; Hill et al., 1992; Lehtonen, 1996). We found that the relationship was a positive exponential with a mean exponent of 1.4, indicating that lipids accumulate at a more rapid rate relative to body size as individuals mature. The difference in results may be due to the wider size range of individuals that we examined (2-11 mm, compared with only larger individuals in the other studies). Our findings do, however, agree with several other studies that have examined lipid accumulation in crustaceans. For example, in adult Gammarid amphipods of a standard length and weight, lipid content increased more rapidly during the later stages of development as accumulation occurred in the ovaries (Clarke et al.,
1985). Also, an exponential increase in lipid content with body size was found for the opposum shrimp, Mysis relicta (Adare \& Lasenby, 1994). Both Diporeia and Mysis relicta are glacial marine relicts that inhabit cold-water habitats below the thermocline, have the same reproductive strategies (brood eggs for many months and release live young), and have comparably high lipid stores (Cavaletto \& Gardner, 1998).

The physiological condition of Diporeia was better in the north compared to the south as evidenced by significantly greater lipid content and weight per unit length. Exact reasons for this difference are not clear, but we suggest that it was due to regional differences in benthic inputs of diatoms. Lipid content of Diporeia is closely related to the deposition of diatoms from the pelagic (Gardner et al., 1985a, 1989), and recent evidence suggests that diatom input is greater in the north. Sediment traps located just below the thermocline in depositional basins in both the north and south showed that the annual mass flux of total biogenic silica, an indicator of diatom input, was 1.7 times greater in the north compared to the south ( $\mathrm{T}$. Johengen, unpublished data collected in 1994). Also, silica concentrations in surficial sediment from the depositional areas were 2.5 times higher in the north.

While higher diatom inputs in the north may be a natural occurrence (personal communication, Eugene

Table 3 Mean lipid class composition (percentage of total lipid content) of Diporeia in each of three regions in Lake Michigan. $\mathrm{HC}=$ hydrocarbons, $\mathrm{SE} / \mathrm{ME}=$ sterol $/$ methyl esters, $\mathrm{TAG}=$ triacylglycerols, FFA $=$ free fatty acids, $\mathrm{ALC}=$ alcohol, $\mathrm{ST} / \mathrm{DG}=$ sterol $/$ diacylglycerols, $\mathrm{AMPL}=$ acetone-mobile polar lipids (e.g. pigments), $\mathrm{PHL}=$ phospholipids

\begin{tabular}{|c|c|c|c|c|c|c|c|c|}
\hline \multirow[b]{2}{*}{ Region } & \multicolumn{8}{|c|}{ Lipid class } \\
\hline & $\mathrm{HC}$ & $\mathrm{SE} / \mathrm{ME}$ & TAG & FFA & ALC & $\mathrm{ST} / \mathrm{DG}$ & AMPL & PHL \\
\hline South & 0.3 & 0.5 & 40.2 & 2.1 & 2.2 & 6.2 & 6.5 & 42.0 \\
\hline Central & 0.2 & 0.3 & 44.2 & 2.4 & 1.3 & 7.5 & 7.9 & 36.2 \\
\hline North & 0.4 & 0.2 & 45.1 & 2.0 & 1.2 & 7.0 & 8.1 & 36.1 \\
\hline
\end{tabular}

(C) 2000 Blackwell Science Ltd, Freshwater Biology, 43, 107-119 
Table 4 Relationship between length and dry weight for Diporeia in three regions of Lake Michigan. The relationship is defined by: $\ln D W=a+b^{*} \ln L$; where $D W=$ dry weight $(\mathrm{mg})$ and $L=$ length $(\mathrm{mm})$. Standard error in parentheses, $n=$ total number of animals

\begin{tabular}{lllrr}
\hline Region & $a$ & $b$ & $n$ & $r^{2}$ \\
\hline South & $-3.768(0.108)$ & $2.017(0.060)$ & 234 & 0.831 \\
Central & $-4.526(0.105)$ & $2.524(0.058)$ & 72 & 0.964 \\
North & $-4.151(0.106)$ & $2.421(0.060)$ & 193 & 0.894 \\
Lake-Wide & $-4.064(0.073)$ & $2.265(0.041)$ & 499 & 0.861 \\
\hline
\end{tabular}

Stoermer, University of Michigan), the establishment of D. polymorpha may have contributed to a lower physiological state in the south by decreasing food availability. Current studies are examining changes in benthic food inputs since the establishment of D. polymorpha, but comparisons between our lipid values and those reported before the introduction of D. polymorpha indicate a decline has occurred. Seasonal changes in lipid content of Diporeia (length $\geqslant 4.5 \mathrm{~mm}$ ) were measured in four separate years between 1984 and 1989 at a 45-m site in the southern basin off Grand Haven (Gardner et al., 1985a; Gauvin, Gardner \& Quigley, 1989; Cavaletto et al., 1996). In each of these studies, lipid levels were no lower than $25 \%$ in late summer. In this study, mean lipid content of similar-sized Diporeia at the same $45-\mathrm{m}$ site was $17.2 \%$, and averaged $18.2 \%$ at all sites within the 30 $50 \mathrm{~m}$ interval in the southern basin. Similarly, levels were greater than $20 \%$ at a $100-m$ site off Grand Haven in 1988 and 1989 (Cavaletto et al., 1996). In this study, mean lipid content at the same $100-\mathrm{m}$ site was $18.9 \%$, and averaged $13.8 \%$ at all sites deeper than $90 \mathrm{~m}$. Weight per unit length has also apparently declined since the 1980s. The weight of a standard 5$\mathrm{mm}$ individual was about $0.87 \mathrm{mg}$ at a $42-\mathrm{m}$ site in the southern basin in late summer 1982 (Winnell \& White, 1984), but was $0.68 \mathrm{mg}$ at the $30-50 \mathrm{~m}$ interval in this study.

Although D. polymorpha was most abundant in nearshore areas of the southern basin (Nalepa et al., 1998), impacts on Diporeia can extend beyond this particular zone. Physical processes laterally transport organic material produced in nearshore areas to areas offshore (Meyers \& Eadie, 1993). Thus, filtering activities of D. polymorpha in nearshore areas can reduce benthic inputs in areas offshore and have an impact on the physiological condition of Diporeia over a wide area. Since D. polymorpha initially became established in the southern end (Marsden, Trudeau \&
Keniry, 1993), we assume that impacts on Diporeia would have been greater in the south than in the north at the time of our sampling.

The mean proportion of TAG, the energy storage lipid, was $40-45 \%$ for the three regions. As for total lipids, these percentages are low compared to previous estimates in Lake Michigan. For instance, over a 2-year period in the late 1980s, the minimum annual mean proportion of TAG in Diporeia with a length $\geqslant 4.5 \mathrm{~mm}$ from a $45-\mathrm{m}$ and a $100-\mathrm{m}$ site in southern Lake Michigan was $76 \%$ and $56 \%$, respectively, and not lower than $50 \%$ in late summer (Cavaletto et al., 1996). Also, at a 45-m site in southern Lake Michigan in 1986, the proportion of TAG in Diporeia $\geqslant 5 \mathrm{~mm}$ was $41 \%$ for juveniles and $81 \%$ for mature individuals in December when food availability was probably at a minimum (Quigley, Chandler \& Gardner, 1989). In our study, the mean TAG level for animals ??4.5 $\mathrm{mm}$ in the southern basin was $45 \%$, and was $60 \%$ and $29 \%$ at the same $45-\mathrm{m}$ and $100-$ $\mathrm{m}$ sites of Cavaletto et al. (1996). Our values were lower than those reported for M. affinis in the Baltic Sea; Hill et al. (1992) reported that mean TAG levels in M. affinis were not lower than $66 \%$ in June and September. To further compare these populations, we used the regression equation provided by Lehtonen (1996), which described the direct relationship between total lipid content and TAG for mature M. affinis in the Baltic on an annual basis. If values of total lipid content in mature Lake Michigan Diporeia are placed into this equation, predicted percentages of TAG in total lipid were $77.6 \%$ and $84.7 \%$ in the south and north regions, respectively. The actual mean percentages were only $52 \%$ and $55 \%$.

In examining lakewide relationships among measured variables, a significant correlation was evident only for the two physiological variables, mean lipid content and length-weight (as weight of a standard 5-mm animal). This may have been 
expected since both variables are closely associated with available food (Gauvin, Gardner \& Quigley, 1989), and both were strongly related to sampling depth. The lack of any significant correlations between mean population and physiological variables would indicate that factors besides food availability differentially influence these variables. For example, in Lake Michigan many fish species feed on Diporeia and, since they tend to select for larger individuals (Evans et al., 1990), variations in predation pressure can lead to changes in both densities and sizefrequencies (Johnson \& McNeil, 1986; McDonald, Crowder \& Brandt, 1990). Fish species that feed heavily on Diporeia are spatially aggregated within the lake (Fabrizio, Ferreri \& Hansen, 1995; Rand et al., 1995) and may have contributed to spatial variation in population density and mean size independent of factors influencing physiological condition.

Our finding of an overall mean lipid content of $16.6 \%$, and a mean of $17.4 \%$ in the favourablehabitatat $30-50 \mathrm{~m}$, indicates a stressed population in the southern basin. Diporeia starved for nearly 200 days had a lipid content of 15\% (Gauvin, Gardner \& Quigley, 1989), while the lipid content of $M$. affinis in winter and early spring when food was limited was also about 15\% (Hill et al., 1992). A lipid level of $15 \%$ is probably the minimum 'weight-specific' lipid content since non-lipid weight loss also occurs during food limitation as evidenced by lower length-weight comparisons in the southern region. Lipid stores are used for the development of reproductive tissue and embryos, and it has been suggested that a lipid content of at least $20 \%$ is needed for reproduction to occur in these holarctic amphipods (Hill et al., 1992). Mean lipid content of mature individuals $(6 \mathrm{~mm})$ in the southern region was $20 \%$ during late summer when reproductive development occurs in Lake Michigan. Thus, even minor declines in lipid content in the future may lead to reductions in reproductive capacity and a subsequent decline in abundances over a wide area. While population trends are being monitored in the southern basin (Nalepa et al., 1998; Nalepa, unpublished data), densities given in this study provide a baseline to assess future population trends throughout the entire lake.

\section{Acknowledgments}

We thank the following people whose contributions are appreciated: D. Morse, B. Burns, and J. Grimes for their support during ship operations; Pat Van Hoof, G. Gostenik, and A. Vielmetti for assisting in field collections; P. Landrum and M. Quigley for helpful comments on the manuscript; L. Herche for statistical advice; and C. Darnell for editorial assistance. This is GLERL contribution no. 1135.

\section{References}

Adare K.I. \& D.C.Lasenby. (1994) Seasonal changes in the total lipid content of the opossum shrimp, Mysis relicta (Malacostraca: Mysidacea). Canadian Journal of Fisheries and Aquatic Sciences, 51, 1935-1941.

Alley W.P. \& Mozley S.C. (1975) Seasonal abundance and spatial distribution of Lake Michigan macrobenthos. 196467. Special Report No. 54 of the Great Lakes Research Division, The University of Michigan, 103 pp.

Bartone C.R. \& Schelske C.L. (1982) Lake-wide seasonal changes of limnological conditions in Lake Michigan in 1976. Journal of Great Lakes Research, 8, 413-427.

Bousfield E.L. (1989) Revised morphological relationships within the amphipod genera Pontoporeia and Gammaracanthus and the 'glacial relict' significance of their post glacial distributions. Canadian Journal of Fisheries and Aquatic Sciences, 46, 1714-1725.

Cavaletto J.F. \& Gardner W.S. (1998) Seasonal dynamics of lipids in freshwater benthic invertebrates. Lipids in Freshwater Ecosystems (eds M.T. Arts and B.C. Wainman), pp. 109-131. Springer, New York.

Cavaletto J.F., Nalepa T.F., Dermott R., Gardner W.S., Quigley M.A. \& Lang G.A. (1996) Seasonal variation of lipid composition, weight, and length in juvenile Diporeia spp. (Amphipoda) from lakes Michigan and Ontario. Canadian Journal of Fisheries and Aquatic Sciences, 53, 2044-2051.

Cederwall H. (1977) Annual macrofauna production of a soft bottom in the northern Baltic proper. Biology of Benthic Organisms (eds B. F. Keegan, P. O. Ceidigh and P. J. S. Boaden), pp. 155-164. Pergamon Press, New York, NY.

Clarke A., Skadsheim A. \& Holmes L.J. (1985) Lipid biochemistry and reproductive biology in two species of Gammaridae (Crustacea: amphipoda). Marine Biology, 88, 247-263.

Cook D.G. \& Johnson M.G. (1974) Benthic macroinvertebrates of the St. Lawrence Great Lakes. Journal of the Fisheries Research Board of Canada, 31, 763-782.

Dadswell M.J. (1974) Distribution ecology and postglacial dispersal of certain crustaceans and fishes in eastern North America. Natural Museum of Natural Science (Ottawa), Publications in Zoology , 11, 1-110.

Dermott R. \& Kerec D. (1997) Changes in the deepwater benthos of eastern Lake Erie since the invasion of 
118 T. F. Nalepa et al.

Dreissena: 1979-93. Canadian Journal of Fisheries and Aquatic Sciences, 54, 922-930.

Evans M.S., Quigley M.A. \& Wojcik J.A. (1990) Comparative ecology of Pontoporeia hoyi populations in southern Lake Michigan: the profundal region versus the slope and shelf regions. Journal of Great Lakes Research, 16, 27-40.

Fabrizio M.C., Ferreri C.P. \& Hansen M.J. (1995) Prey fish communities as indicators of ecosystem health in Lake Michigan. Project Completion Report to the Environmental Protection Agency. Great Lakes Science Center, U.S. Geological Survey, Ann Arbor, MI.

Gardner W.S., Eadie B.J., Chandler J.F., Parrish C.C. \& Malczyk J.M. (1989) Mass flux and 'nutritional composition' of settling epilimnetic particles in Lake Michigan. Canadian Journal of Fisheries and Aquatic Sciences, 46, 1118-1124.

Gardner W.S., Nalepa T.F., Frez W.A., Cichocki E.A. \& Landrum P.F. (1985a) Seasonal patterns in lipid content of Lake Michigan macroinvertebrates. Canadian Journal of Fisheries and Aquatic Sciences, 42, 1827-1832.

Gardner W.S., Frez W.A., Cichocki E.A. \& Parrish C.C. (1985b) Micromethod for lipids in aquatic invertebrates. Limnology and Oceanography, 30, 1099-1105.

Gardner W.S., Quigley M.A., Fahnenstiel G.L., Scavia D. \& Frez W.A. (1990) Pontoporeia hoyi - a direct trophic link between spring diatoms and fish in Lake Michigan. Large Lakes: Ecological Structures and Functions (Eds M. M .Tilzer and C. Serruya), pp. 632-644. SpringerVerlag, New York, NY.

Gauvin J.M., Gardner W.S. \& Quigley M.A. (1989) Effects of food-removal on nutrient-release rates, lipid content and survival time of Lake Michigan Pontoporeia hoyi. Canadian Journal of Fisheries and Aquatic Sciences, 46, 1125-1130.

Hadley N.F. (1985) The Adaptive Role of Lipids in Biological Systems. John Wiley and Sons, New York, NY.

Hill C., Quigley M.A., Cavaletto J.F. \& Gordon W. (1992) Seasonal changes in lipid content and composition in the benthic amphipods Monoporeia affinis and Pontoporeia femorata. Limnology \& Oceanography, 37, 1280-1289.

Johnson M.G. \& McNeil O.C. (1986) Changes in abundance and species composition in benthic macroinvertebrate communities of the Bay of Quinte, 19661984. Project Quinte: Point-Source Phosphorus Control and Ecosystem Response in the Bay of Quinte, Lake Ontario (Eds C. K. Minns, D. A. Hurley and K. H. Nicholls) Canadian Special Publication of Fisheries and Aquatic Sciences, 86, 270 pp.

Johnson R.K. \& Wiederholm T. (1992) Pelagic-benthic coupling - the importance of diatom interannual variability for population oscillations of Monoporeia affinis. Limnology and Oceanography, 37, 1596-1607.
Lauritsen D.D., Mozley S.C. \& White D.S. (1985) Distribution of oligochaetes in Lake Michigan and comments on their use as indices of pollution. Journal of Great Lakes Research, 11, 67-76.

Lehtonen K.K. (1995) Geographical variability in the bioenergetic characteristics of Monoporeia/Pontoporeia spp. populations from the northern Baltic Sea, and their potential contribution to benthic nitrogen mineralization. Marine Biology, 123, 555-564.

Lehtonen K.K. (1996) Ecophysiology of the benthic amphipod Monoporeia affinis in an open-sea area of the northern Baltic Sea: seasonal variations in body composition, with bioenergetic considerations. Marine Ecology Progress Series, 143, 87-98.

Lubner J.F. (1979) Population dynamics and production of the relict amphipod, Pontoporeia hoyi, at several Lake Michigan stations. PhD Thesis, University of Wisconsin, Milwaukee, WI.

Marsden J.E., Trudeau N. \& Keniry T. (1993) Zebra Mussel Study of Lake Michigan. Aquatic Ecology Technical Report 93/14, Illinois Natural History Survey, Zion, IL. McDonald M.E., Crowder L.B. \& Brandt S.B. (1990) Changes in Mysis and Pontoporeia populations in southeastern Lake Michigan: a response to shifts in the fish community. Limnology and Oceanography, 35, 220-227.

Meyers P.A. \& Eadie B.J. (1993) Sources, degradation and recycling of organic matter associated with sinking particles in Lake Michigan. Organic Geochemistry, 20, 47-56.

Moore J.W. (1976) The proximate and fatty acid composition of some estuarine crustaceans. Estuarine and Coastal Marine Science, 4, 215-224.

Mortimer C.H. (1975) Environmental Status of the Lake Michigan Region, 2: Physical Limnology of Lake Michigan, Part 1, Physical characteristics of Lake Michigan and its responses to applied forces. ANL/ES-40, Argonne National Laboratory, U. S. Energy Research and Development Administration.

Mozley S.C. \& Howmiller R.P. (1977) Environmental Status of the Lake Michigan Region, Vol. 6: Zoobenthos of Lake Michigan. ANL/ES-40, Argonne National Laboratory, U.S. Energy Research and Development Administration.

Nalepa T.F. (1987) Long term changes in the macrobenthos of southern Lake Michigan. Canadian Journal of Fisheries and Aquatic Sciences, 44, 515-524.

Nalepa T.F. (1989) Estimates of macroinvertebrate biomass in Lake Michigan. Journal of Great Lakes Research, 15, 437-443.

Nalepa T.F., Hartson D.J., Fanslow D.L., Lang G.A. \& Lozano S.J. (1998) Decline of benthic macroinvertebrate populations in southern Lake Michigan. 1980-93. Canadian Journal of Fisheries and Aquatic Sciences, 55, 2402-2413. 
Nalepa T.F., Quigley M.A., Childs K.F., Gauvin J.M., Heatlie T.S., Parker M.P. \& Vanover L. (1985) Macrobenthos of southern Lake Michigan, 1980-81. NOAA Data Report ERL GLERL-28. Great Lakes Environmental Research Laboratory, Ann Arbor, MI.

Napolitano G.E. \& Ackman R.G. (1989) Lipids and hydrocarbons in Corophium volutator from Minas Basin, Nova Scotia. Marine Biology, 100, 333-338.

Parrish C.C. (1987) Separation of aquatic lipid classes by Chromarod thin-layer chromatography with measurement by Iatroscan flame ionization detection. Canadian Journal of Fisheries and Aquatic Sciences, 44, 722-731.

Quigley M.A., Chandler J.F. \& Gardner W.S. (1989) Lipid composition related to body size and maturity of the amphipod Pontoporeia hoyi. Journal of Great Lakes Research, 15, 601-610.

Quigley M.A. \& Lang G.A. (1989) Measurement of amphipod body length using a digitizer. Hydrobiologia, 171, 255-258.

Quigley M.A. \& Vanderploeg H.A. (1991) Ingestion of live filamentous diatoms by the Great Lakes amphipod, Diporeia sp.: a case study of the limited value of gut contents. Hydrobiologia, 223, 141-148.

Rand P.S., Stewart D.J., Lantry B.F., Rudstram L.G., Johannsson O.E., Goyke A.P., Brandt S.B., O'Gorman R. \& Eck Q.W. (1995) Effect of lake-wide planktivory by the pelagic prey fish community in Lakes Michigan and Ontario. Canadian Journal of Fisheries and Aquatic Sciences, 52, 1546-1563.
Robertson D.M. (1997) Regionalized loads of sediment and phosphorus to Lakes Michigan and Superior high flow and long-term average. Journal of Great Lakes Research, 23, 416-439.

Scavia D., Fahnenstiel. G.L., Evans M.S., Jude D.J. \& Lehman J.T. (1986) Influence of salmonid predation and weather on long-term water quality trends in Lake Michigan. Canadian Journal of Fisheries and Aquatic Sciences, 43, 435-443.

Schelske C.L. (1977) Trophic status and nutrient loading for lake Michigan. North American Project - A Study of U. S. Water Bodies: A Report for the Organization of Economic Cooperation and Development. Report No. EPA-600/377-086, Ecol. Res. Series, U. S. Environmental Protection Agency, Corvallis, OR.

Sly P.G. \& Christie W.J. (1992) Factors influencing densities and distributions of Pontoporeia hoyi in Lake Ontario. Hydrobiologia, 235-236, 321-352.

Stevens D.L. Jr (1997) Variable density grid-based sampling designs for continuous spatial distributions. Environmetrics, 8, 167-195.

Winnell M.H. \& White D.S. (1984) Ecology of shallow and deep water populations of Pontoporeia hoyi (Smith) (Amphipoda) in Lake Michigan. Freshwater Invertebrate Biology, 3, 118-138.

(Manuscript accepted 20 July 1999) 